\title{
Új lehetőség a daganatos fájdalom csillapításában Magyarországon: rövid hatású major analgetikumok
}

\author{
Kullmann Tamás dr. ${ }^{1}$ - Sipőcz István dr. ${ }^{1}$ \\ Csikós Ágnes dr. ${ }^{2}$ - Pintér Tamás dr. ${ }^{1}$ \\ ${ }^{1}$ Petz Aladár Megyei Oktató Kórház, Onkoradiológiai Osztály, Győr \\ ${ }^{2}$ Pécsi Tudományegyetem, Általános Orvostudományi Kar, Családorvostani Intézet, \\ Hospice-Palliatív Tanszék, Pécs
}

\begin{abstract}
A közelmúltban a magyar gyógyszerpiac nagy hiányosságát pótolták: ismét törzskönyvi engedélyt kapott a szájon át adható rövid hatástartamú morfin. A rövid hatású morfinnak két indikációs területe van: a major analgetikus kezelés bevezetésekor a megfelelő dózis titrálása, valamint a fenntartó major analgetikus kezelés mellett jelentkező áttöréses fájdalmak kezelése. A cikk bemutatja a szájon át adható rövid hatástartamú morfin klinikai alkalmazásának alapjait. Orv. Hetil., 2015, 156(25), 1003-1006.
\end{abstract}

Kulcsszavak: daganatos fájdalom, áttöréses fájdalom, morfin, titrálás

\section{New option in the management of cancer pain in Hungary: short acting oral opioid therapy}

Short acting oral morphine has recently been registered again in Hungary. Short acting oral morphine has two essential indications: dose titration at initiation of major analgesic therapy and treatment of breakthrough pain appearing beside round the clock major analgesic therapy. The clinical management of short acting oral morphine is summarised in this article.

Keywords: cancer pain, breakthrough pain, morphine, dose titration

Kullmann, T., Sipöcz, I., Csikós, Á., Pintér, T. [New option in the management of cancer pain in Hungary: short acting oral opioid therapy]. Orv. Hetil., 2015, 156(25), 1003-1006.

(Beérkezett: 2015. március 22.; elfogadva: 2015. április 23.)

Magyarországon évente több mint 30000 ember hal meg daganatos betegségben [1]. A betegek többségét szorongással tölti el a kiszolgáltatottság gondolata, és több mint kétharmaduk az életük végén inkább otthoni ellátásban szeretne részesülni [2]. A betegek háromnegyede a betegség hosszabb-rövidebb szakaszában erős fájdalmakat él át, ezért opiát típusú fájdalomcsillapító kezelésre szorul [3]. A daganatos fájdalom csillapítására tehát a betegek által kontrollálható gyógyszerformák volnának kívánatosak.

A daganatos fájdalom természete szerint hullámzó erősségű [4] (1.ábra). Optimális fájdalomcsillapítás csak hosszú és rövid hatástartamú gyógyszerek kombinációjá- val érhető el. Franciaországban az orvosi gyakorlat olyan fontosnak tartja a rövid hatástartamú készítmények szerepét, hogy fenntartó kábítószer rendelése mellé törvényi szabályozás írja elő a várható áttöréses fájdalmakra kiegészítő dózis rendelését [4].

Magyarországon a major analgetikumok elérhetősége terén két hiányosság tapasztalható. Egyrészt európai öszszehasonlításban a kábító fájdalomcsillapítók alkalmazása alacsony [5], másrészt a rövid hatástartamú készítmények 3 éven át hozzáférhetetlenek voltak.

A korábban forgalomban lévő rövid hatástartamú morfinkészítmény, a Sevredol törzskönyvi engedélyét a forgalmazó cég 2011-ben nem hosszabbította meg. 


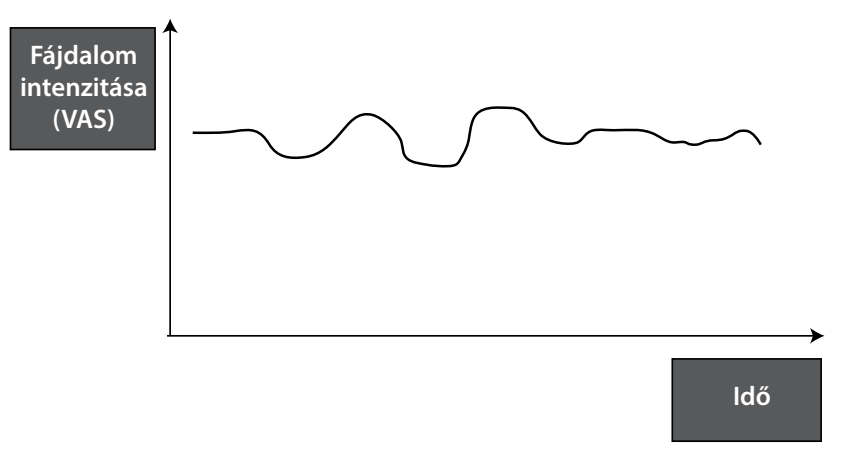

1. ábra

A nyugalmi daganatos fájdalom időbeni ingadozása (VAS: vizuális analóg skála)

A döntés hátterében a kis kereslet állt. A gyógyszert a forgalmazó cég saját adatai szerint országszerte havonta csupán mintegy 50 betegnek írták fel. Így a gyógyszerforgalom árbevétele messze nem termelte ki a törzskönyv ötéves meghosszabbításának adminisztratív költségét.

A parlament 2013-ban törvényt fogadott el a kedvezményezett gyógyszer státusról (CCXLIV/2013). A törvény szerint a kedvezményezett státusról az egészségbiztosítási szerv dönt. Kedvezményezett státust kaphat az a terápiában nélkülözhetetlen gyógyszer, amelynek a hazai forgalmazása az alacsony betegszám és a forgalomba hozatali engedély fenntartásának magas költségei miatt ellehetetlenül (és ezért csak egyedi beszerzési/engedélyezési eljárással lehetne hozzájutni). A jogszabály megalkotásával elhárult az akadály a rövid hatástartamú, szájon át adható morfinkészítmények alkalmazhatósága elől. 2015-ben a Sevredol ismét törzskönyvi engedélyt kapott.

A rövid hatású morfinnak két indikációs területe van: a major analgetikus kezelés bevezetésekor a megfelelő dózis titrálása, valamint a fenntartó major analgetikus kezelés mellett jelentkező áttöréses fájdalmak kezelése [6].

\section{A rövid hatástartamú major analgetikumok típusai}

Rövid hatású major analgetikumoknak nevezzük azokat a morfinszármazékokat, amelyeknek a hatástartama körülbelül 4 óra. A gyógyszercsoporton belül megkülönböztetünk gyors és azonnali hatású készítményeket.

A gyors hatású major analgetikumok hatása a bevételt követően mintegy 20-30 perc múlva érzékelhető. A nemzetközi piacon két major analgetikumnak van gyors hatástartamú kiszerelése, a morfinnak és az oxycodonnak [4].

$\mathrm{Az}$ azonnali hatású major analgetikumok hatása a bevételt követóen körülbelül 5-10 perc múlva érzékelhető. A nemzetközi piacon két major analgetikumnak van azonnali hatású kiszerelése, a fentanylnak (tabletta és orrspray formájában is) és az oxycodonnak [4]. Az azonnali hatású készítmények előnye a gyors hatástartamúakhoz képest a hatás elérésének gyorsasága, hátrányuk a magasabb ár.

\section{A major analgetikus kezelés bevezetése}

Major analgetikus kezelést akkor szükséges indítani, amikor nociceptív típusú fájdalmakat maximális adagú (napi $400 \mathrm{mg}$ ) tramadol és (napi 4-6 g) paracetamol kombinációja nem csökkenti elegendő mértékben [7]. A WHO fájdalomcsillapító-lépcsőjén ez a másodikról a harmadik fokra lépést jelenti. A major analgetikus kezelés optimális kezdő dózisa nem minden betegnél egyforma, és személyre szabottan titrálással határozható meg legpontosabban.

A per os morfintitrálás menete a következő: A beteg $10 \mathrm{mg}$ rövid hatástartamú morfintablettát vesz be. Ha fél óra várakozást követően fájdalmai megfelelő mértékben csökkennek, további tablettát nem szed mindaddig, amíg a fájdalmak ki nem újulnak. Ha fél óra várakozást követően fájdalmai nem csökkennek elfogadható mértékben, akkor újabb $10 \mathrm{mg}$-os tablettát vesz be. Ha a későbbiekben újra visszatér az erôs fájdalom, újabb tablettát szedhet. 24 óra elteltével összegezzük a teljes napi dózist és az alapján rendelünk fenntartó kezelést.

Ha a fenntartó kezelés morfin, akkor egyszerú a számítás, a rövid hatású morfintablettákból szedett teljes napi dózis felét kapja reggel, felét este retard készítmény formájában. Ha a fenntartó kezelés oxycodon, akkor a rövid hatású morfintablettákból szedett teljes napi dózis negyedét kapja reggel, negyedét este retard készítmény formájában. (Az oxycodon hatáserőssége a morfin hatáserősségének duplája.) Ha a fenntartó kezelés hydromorfon, akkor a rövid hatású morfintablettákból szedett teljes napi dózis nyolcadát kapja naponta egyszer retard készítmény formájában. (A hydromorfon hatáserőssége a morfin hatáserősségének nyolcszorosa.) Ha a fenntartó kezelés fentanyl, akkor a rövid hatású morfintablettákból szedett teljes napi dózis századát adó tapaszt kap háromnaponta. (A fentanyl hatáserőssége a morfin hatáserősségének százszorosa.) Tekintettel arra, hogy a tapaszokat az óránként leadott dózis alapján tartjuk számon, egyszerúbb számolással a milligrammban kifejezett napi morfindózisnak mikrogrammban kifejezett 2,4 részét adó tapaszt kell választani. A morfinszármazékok ekvivalenciadózisait az 1. táblázat foglalja össze.

Például, ha egy betegnek a fájdalom kontrollálására a titrálás során 24 óra alatt 6 darab 10 mg-os rövid hatású morfin-szulfátra volt szüksége, akkor retard morfinból

1. táblázat |A major analgetikumok ekvivalenciadózisai

\begin{tabular}{cccc}
\hline Morfin & Oxycodon & Hydromorfon & Fentanyl \\
\hline $10 \mathrm{mg} \mathrm{x2}$ & $5 \mathrm{mg} \mathrm{x2}$ & & \\
$20 \mathrm{mg} \mathrm{x2}$ & $10 \mathrm{mg} \mathrm{x2}$ & & $12 \mu \mathrm{g} / \mathrm{h}$ \\
$30 \mathrm{mg} \mathrm{x2}$ & $15 \mathrm{mg} \mathrm{x2}$ & $8 \mathrm{mg}$ & $25 \mu \mathrm{g} / \mathrm{h}$ \\
$40 \mathrm{mg} \mathrm{x2}$ & $20 \mathrm{mg} \mathrm{x2}$ & & $37 \mu \mathrm{g} / \mathrm{h}$ \\
$60 \mathrm{mg}$ x2 & $30 \mathrm{mg} \mathrm{x2}$ & $16 \mathrm{mg}$ & $50 \mu \mathrm{g} / \mathrm{h}$ \\
$90 \mathrm{mg} \times 2$ & $45 \mathrm{mg} \times 2$ & $24 \mathrm{mg}$ & $75 \mu \mathrm{g} / \mathrm{h}$ \\
\hline
\end{tabular}


$2 \times 30 \mathrm{mg}$, oxycodonból $2 \times 15 \mathrm{mg}$, hydromorfonból $1 \times 8$ mg, fentanyltapaszból 3 naponta 1 darab $25 \mu \mathrm{g} / \mathrm{h}$ lesz a fenntartó kezelése.

A jelenlegi magyar gyakorlat szerint a rövid hatástartamú major analgetikumok hiányában első lépésben fentanyltapaszt szoktak felhelyezni 25 vagy $50 \mu \mathrm{g} / \mathrm{h}$ kezdő dózisban. Ennek a gyakorlatnak egyik hátránya, hogy könnyen rögtön a kezelés megkezdésekor túladagolást okoz. A titrálás előnye, hogy alkalmazásával elkerülhető a túladagolás.

\section{$\mathrm{Az}$ áttöréses fájdalmak kezelése}

A fájdalom pontos kifejezésére a szókincsünk jelenleg szegényes. Pedig, mivel a fájdalom csak a beteg által megélt szubjektív érzés, és a vizsgáló orvosnak, valamint az ápolószemélyzetnek nem áll rendelkezésére a beteg által megélt fájdalom mérésére alkalmas eszköz, a hatékony fájdalomcsillapítás elengedhetetlen feltétele a szót értés.

Áttöréses fájdalomnak nevezzük a fenntartó major analgetikus kezelés mellett fellépő, rövid ideig (néhány perctől egy-két óráig) tartó fájdalmakat. Az áttöréses fájdalmak elsősorban abból a természetes jelenségből származnak, hogy a fájdalmak hullámzó erôsségűek [3], ezzel szemben a retard morfinszármazékok állandó gyógyszerszintet biztosítanak. A hullámzó erősségű fájdalom állandó gyógyszerszinttel azonban csak úgy kezelhető, hogy időnként vagy túldozírozást, vagy aluldozírozást okozunk. (Ezenkívül áttöréses fájdalmat okozhat, ha a retard készítmény a gyógyszer-metabolizmus egyéni variációja révén nem tart ki 12,24 , illetve 72 óráig. Továbbá mozgás vagy mozgatás is fokozza a nyugalmi fájdalmat.)

Az áttöréses fájdalmak kezelésére a rövid hatástartamú morfinszármazékok alkalmasak [4]. Egyszeri dózisuk a fenntartó napi dózis hatoda (a félnapi dózis harmada). Szedésük naponta egy-három alkalommal ismételhető. Amennyiben naponta háromnál többször is szükség van szedésükre, akkor a fenntartó kezelés adagjának emelése válhat szükségessé.

A rövid hatástartamú gyógyszerek ilyen módon a fenntartó kezelés dózisának optimalizációját is segítik. Rávezethetnek például egymástól eltérő nappali és éjszakai dózis beállítására. Hiszen vannak olyan fekvő betegek, akik nappal jól elviselik fájdalmukat, de éjszaka forgolódás közben mégis gyakran felébreszti őket. Ezek a betegek a reggelinél magasabb esti fájdalomcsillapító adagot igényelnek. Fordítva, fennjáró betegeknél előfordul, hogy ugyan jól alszanak, de nappali aktivitásukat gátolja a mozgásra jelentkező erős fájdalom [4]. Ezek a betegek magasabb reggeli fájdalomcsillapító-adagot igényelnek. Az eltérő reggeli és esti dozírozás persze csak a 12 órás hatástartamú retard készítményekkel érhető el.

Amennyiben a fenntartó major analgetikus kezelés mellett állandó fájdalmat jelez a beteg, az általában a daganatos betegség progressziójának a jele. Csillapítására az ismételten adott rövid hatástartamú morfin csak átmenetileg javasolható. A megoldást a fenntartó dózis emelése jelenti, amelynek helyes mértéke a korábbi dózis egyharmada. Tehát a dózisemelés mértéke függ a megelőzően alkalmazott dózistól [4].

Amennyiben a fenntartó major analgetikus kezelés mellett rövid ideig, akár csak néhány pillanatig vagy percig tartó fájdalmak lépnek fel, akkor a rövid hatású morfinkészítmények a farmakokinetikai korlátok miatt nem alkalmasak a csillapításukra. Az ilyen rövid ideig tartó fájdalmak általában nem nociceptív, hanem neuropathiás eredetűek, így kontrollálásuk nem csillapítással, hanem megelőzéssel oldható meg. A hazai gyakorlatban leginkább elterjedt neuropathiás fájdalomcsillapítók, a carbamazepin és amitriptylin hatástalansága esetén a gabapentin alkalmazását javasoljuk. A gabapentin bevezetése fokozatosságot igényel, két-három naponta emelve a dózist 25-50 mg-mal [4].

Léteznek néhány percig tartó nociceptív fájdalmak is. Ezekre a magyar szaknyelv még nem talált egységesen elfogadott elnevezést. Magunk részéről a hirtelen áttöréses fájdalom megnevezést javasoljuk. A nociceptív típusú hirtelen áttöréses fájdalmak az összes áttöréses fájdalomhoz képest lényegesen ritkábban fordulnak elő. Ez az a terület, ahol a Magyarországon jelenleg nem elérhető azonnali hatású major analgetikumok használatára szükség lehet [4].

\section{A major analgetikumok mellékhatásai}

A major analgetikumok 2. táblázatban felsorolt mellékhatásai jól ismertek. Megfordítva, a daganatos betegeknél fellépő asthenia esetén azonban előfordulhat, hogy nem gondolnak iatrogeniára. Különösen két szituáció lehet csapda:

- Az egyik veszély, hogy olyan fájdalomra rendelnek morfinszármazékot, amelyre az nem megfelelően hatásos. Típusosan ilyen a fájdalmas csontáttét. Ilyenkor előfordul néhány napon belül gyors dóziseszkaláció,

2. táblázat |A major analgetikumok mellékhatásai

\begin{tabular}{l}
\hline Az opiátok mellékhatásai \\
\hline Székrekedés \\
Hányinger \\
Vizeletretenció \\
Bradycardia \\
Myosis \\
Viszketés \\
Izzadás \\
Rémálmok \\
Zavartság \\
Somnolentia \\
Légzésdepresszió
\end{tabular}


ami a beteget somnolens állapotba hajtja, de éber állapotban még mindig nem csillapítja elegendően a fájdalmát. A stratégia akár a beteg súlyos légzésdepreszsziójához is vezethet. A csontáttétek elsődlegesen választandó gyógyszerei a nem szteroid gyulladásgátlók. A major analgetikumok közül pedig az oxycodon csillapítja leghatásosabban a csontfájdalmakat.

- A másik veszély, hogy hatékony kemoterápiát vagy sugárkezelést indítanak morfinszármazékkal kezelt betegnél. A csökkenő daganatkiterjedés az általa okozott fájdalom csillapodását is magával vonja. A harmadiknegyedik vonalban adott kemoterápia mellett fellépő astheniát könnyen az áttétes daganat progressziójával magyarázzák, olykor még növelik is a morfin adagját, hogy a vélt szenvedést csökkentsék. A stratégia szintén korai légzésdepresszióhoz is vezethet. A megfelelő ellátás ezekben az esetekben a fájdalomcsillapító kezelés felfüggesztése, majd az éberség visszanyerését követően újraindítása alacsonyabb dózisban.

\section{Következtetések}

A rövid hatástartamú, szájon át adható morfinkészítmény ismételt bevezetésével a magyar gyógyszerpiac nagy hiányosságát pótolják. Rövid hatástartamú készítmények nélkül daganatos fájdalmat kezelni ugyanolyan abszurd, mint a cukorbetegség terápiája lenne rövid hatástartamú inzulin nélkül.

A magyar lakosság és az egészségügyi dolgozók körében is számos előítélet él a morfinkezeléssel kapcsolatban $[2,8]$. Széles körü társadalmi és szakmai tájékoztatás szükséges ahhoz, hogy a betegek és az orvosok is megtanuljanak élni az optimális fájdalomcsillapítás elérésének ezzel az eszközével.

A betegek számára a szükség szerint saját maguk által dozírozott fájdalomcsillapító kezelés segíthet a morfin általános elfogadásában. Ezenkívül, amennyiben a gyógyszer forgalma kedvezően alakul, második lépésben a kiemelt társadalombiztosítási támogatás biztosítása is indokolt lesz.

Az orvosok számára jó hír, hogy a korábbi túlzott adminisztratív terhek csökkentek. Major analgetikumok rendelésére a tavalyi évtől egy példányban is elegendő a receptet kiállítani.

Összefoglalva, a rövid hatástartamú major analgetikumok az optimális fájdalomcsillapítás elengedhetetlen eszközei. Használatukat szinte minden orvosi szakterület múvelőinek célszerű lenne elsajátítani. Helyes alkalmazásukkal a morfinkezelés társadalmi elfogadottsága is javítható volna.

Anyagi támogatás: A közlemény megírása anyagi támogatásban nem részesült.

Szerzöi munkamegosztás: K. T.: A cikk nyers változatának elkészítése. Cs. Á.: Szakértői vélemény. S. I., P. T.: A tanulmány korrekciója. A végleges változatot minden szerző elolvasta és jóváhagyta.

Anyagi érdekeltségek: A szerzőknek nincsenek anyagi érdekeltségeik.

\section{Irodalom}

[1] Kásler, M. (ed).: Fundamentals of oncology. [Az onkológia alapjai.] Medicina Könyvkiadó, Budapest, 2011. [Hungarian]

[2] Csikós, Á., Albanese, T., Busa, C., et al.: Hungarians' perspectives on end-of-life care. J. Palliat. Med., 2008, 11(8), 1083-1087.

[3] Heigl, P.: Cancer pain management. [Daganatos fájdalmak csillapítása.] Orv. Hetil., 2014, 155(3), 93-99. [Hungarian]

[4] Jacquemin, D., de Broucker, D. (eds.): Manuel de soins palliatifs. Dunod, Paris, 2014.

[5] http://www.atome-project.eu/documents/final-reports/hungary-legislation.pdf [Hungarian]

[6] http://www.esmo.org/Guidelines/Supportive-Care/Management-of-Cancer-Pain

[7] Embey-Isztin, D. (ed.): Management of pain. [Fájdalomcsillapítás.] White Golden Book Kft., Budapest, 2009. [Hungarian]

[8] Biró, E.: Attitudes of Hungarian adults toward use of opioids in pain management. [Opioidokkal történő fájdalomcsillapítással kapcsolatos attitúdök magyar felnőttek körében.] Orv. Hetil., 2013, 154(12), 455-463. [Hungarian]

(Kullmann Tamás dr., Györ, Vasvári Pál u. 2-4., 9024 e-mail: kullmanndoki@hotmail.com) 